medRxiv preprint doi: https://doi.org/10.1101/2020.12.28.20248949; this version posted January 4, 2021. The copyright holder for this preprint (which was not certified by peer review) is the author/funder, who has granted medRxiv a license to display the preprint in perpetuity.

It is made available under a CC-BY-NC-ND 4.0 International license .

\title{
Histopathological Profile of Cervical Biopsies in Northern Malawi: A Retrospective Study
}

Paul Uchizi Kaseka ${ }^{1 *}$, Alfred Kayira ${ }^{1}$, Chikondi Sharon Chimbatata ${ }^{1}$, Master Chisale ${ }^{1,2,3}$, Pocha Kamudumuli ${ }^{4}$, Tsung-Shu Joseph $\mathrm{Wu}^{2,5}$, BalwaniChingatichifwe Mbakaya, ${ }^{6,7}$ Frank Watson Sinyiza $^{1}$

${ }^{1}$ Mzuzu Central Hospital, Mzuzu City, Malawi

${ }^{2}$ Luke International, Mzuzu City, Malawi

${ }^{3}$ Mzuzu University, Faculty of Sciences, Technology and Innovations, Biological Sciences, Mzuzu City, Malawi

${ }^{4}$ University of Maryland Global Initiative Corporation, Baltimore, Lilongwe City, Malawi

${ }^{5}$ Pingtung Christian Hospital, Taiwan

${ }^{6}$ University of Livingstonia, Department of Public Health, Malawi

${ }^{7}$ Mzuzu University, Faculty of Health Sciences, Mzuzu City, Malawi

*Corresponding author: kasekapau12016@gmail.com

\section{ABSTRACT}

Objectives: This study was carried out to determine the histopathological profile of cervical biopsies in a public tertiary hospital in Mzuzu, northern region of Malawi.

Setting: A public tertiary hospital in Mzuzu, northern region of Malawi

Participants: This was a retrospective study of all cervical biopsy specimen reports received in a public tertiary hospital in northern Malawi over a period of 5 years from July 2013-June 2018. Eleven reports which had missing demographic and clinical data or had inconclusive results were excluded. Demographic, clinical and histopathological data was obtained from original histology reports.

Results: A total of 500 cervical biopsy reports were reviewed during the study period. The mean age of the patients was $41.99 \pm 12.5$. Age ranged from 15 to 80 years. Cervicitis accounted for $46.0 \%(n=162)$ of the total nonmalignant lesions seen, followed by cervical intraepithelial neoplasm (CIN), at $24.4 \%(n=86)$ and endocervical polyp, at $20.5 \%(n=72)$. Squamous cell carcinoma (SCC) accounted for $15.6 \%(n=78)$ of the total 
medRxiv preprint doi: https://doi.org/10.1101/2020.12.28.20248949; this version posted January 4, 2021. The copyright holder for this preprint (which was not certified by peer review) is the author/funder, who has granted medRxiv a license to display the preprint in perpetuity. It is made available under a CC-BY-NC-ND 4.0 International license .

cervical biopsies studied and $85.7 \%$ of all total malignant lesions. All malignant tumours had HIV.

Conclusion: Our study shows that cervicitis and squamous cell carcinoma were most common among nonmalignant and malignant cervical biopsies respectively. Since the frequency of cervical cancer is high, there is need to have well detailed national policies to be put in place to increase detection of pre-invasive lesions in order to reduce the prevalence of cervical cancer.

Key words: Cervical biopsies, cervical cancer, cervical intraepithelial neoplasm, cervicitis, malignant

\section{Strengths and limitation of this study}

\section{Strengths}

This paper has shown

- The need for well detailed national policies to be put in place to increase detection of pre-invasive lesions, which in turn will decrease the frequency of cervical cancer in the country.

- The importance of intensifying cervical cancer screening programmes among women and provision of long term ART to the HIV infected which may offer an opportunity for appropriate interventions to reduce morbidity, mortality and reduce complications among these women.

\section{Limitations}

- This study used available programme health facility data and histopathological reports on cervical cancer which has its own limitations, such as incompleteness and bias in the sense that information is obtained only from people who came to the facility and underwent biopsy, leaving out those that did not seek medical care and or were not biopsied and therefore cannot be generalized to the general population.

- The study is a single-hospital-based review and as such inadequate to draw 
medRxiv preprint doi: https://doi.org/10.1101/2020.12.28.20248949; this version posted January 4, 2021. The copyright holder for this preprint (which was not certified by peer review) is the author/funder, who has granted medRxiv a license to display the preprint in perpetuity. It is made available under a CC-BY-NC-ND 4.0 International license .

conclusions, but it does shed some light on pathological pattern of cervical cancer in Malawi.

\section{BACKGROUND}

Cervical cancer, after breast cancer, is the second most common cancer in women aged 15 to 44 years and it is the third leading cause of cancer in females worldwide(1). According to the International Agency for Research on Cancer (IARC) estimates, there are 570,000 new cases of cervical cancer annually, resulting into more than 311,000 deaths in 2018 globally (2). Most of the global burden lies in less developed countries, with sub-Saharan Africa (SSA) having the largest age-standardized incidence and mortality rates. Malawi has the highest cervical cancer incidence and mortality in the world with age-standardized rate (ASR) of 75.9 and 49.8 per 100,000 population respectively(3). World Health Organization (WHO) estimates suggest that every year there are at least 3,684 new cases of cervical cancer in Malawi and over 2,314 die from the disease(3).The exact number of cervical cancer morbidity and mortality among Malawian women, is not clear. This could partly be due to unrecorded or underreported cases because of the pathological based cancer registry not being maintained, and also lack of a national system of death certification(4). However, the 2010 National population-based cancer registry indicates that among females, cancer of the cervix was the commonest, accounting for $45.4 \%$ of all cases followed by Kaposis sarcoma $(21.1 \%)$, cancer of the oesophagus (8.2\%), breast cancer $(4.6 \%)$ and non-Hodgkin lymphoma (4.1\%)(5).

The standard method for diagnosis of cervical precancerous lesions is histopathological examination of tissue obtained through biopsy guided by colposcopy. When abnormalities are identified, cervical biopsy confirms the diagnosis of cancer(6).This study was carried out to determine the histopathological profile of cervical biopsies in a public tertiary hospital in Mzuzu, northern region of Malawi. The specific objectives were to determine the prevalence of both precancerous and cancerous cervical lesions; characterization of precancerous and cancerous lesions and risk factors of cervical 
medRxiv preprint doi: https://doi.org/10.1101/2020.12.28.20248949; this version posted January 4, 2021. The copyright holder for this preprint (which was not certified by peer review) is the author/funder, who has granted medRxiv a license to display the preprint in perpetuity.

It is made available under a CC-BY-NC-ND 4.0 International license .

cancer. Understanding the histological pattern of cervical cancer could guide development of focused preventive, care and treatment guidelines to address shortfalls in the care that is provided to cervical cancer patients in Malawi. Ultimately, this could contribute to the global target of $25 \%$ reduction of premature mortality from non communicable diseases (NCDs) by the year 2025 .

\section{MATERIALS AND METHODS}

\section{Design, setting and population}

This was a retrospective study of all cervical biopsies reports received from Kamuzu Central Hospital/University of North Carolina (KCH/UNC) pathology laboratory in Lilongwe for Mzuzu Central Hospital (MCH), the only public tertiary hospital in the northern region of Malawi. This hospital does not have a functional pathology laboratory and relies on the $\mathrm{KCH} / \mathrm{UNC}$ pathology laboratory for its services. The hospital is located in the northern part of Malawi catering for a population of about 2,289,780 million people (7) and serving 5 government District Hospitals, 3 Christian Health Association of Malawi (CHAM) hospitals and several private hospitals and clinics.

In this study a total of 500 cervical cancer pathology reports were analyzed over a period of 5 years (June 2013 to July 2018). Eleven reports which had missing demographic and clinical data or had inconclusive results were excluded. Data extracted included age, year, anatomic site, nature of specimen, clinical diagnosis, histopathological diagnosis, HIV status and whether the specimen was nonmalignant or malignant.

\section{Patient and public involvement}

No patient involved

\section{Data analysis}


medRxiv preprint doi: https://doi.org/10.1101/2020.12.28.20248949; this version posted January 4, 2021. The copyright holder for this preprint (which was not certified by peer review) is the author/funder, who has granted medRxiv a license to display the preprint in perpetuity.

It is made available under a CC-BY-NC-ND 4.0 International license .

Data were entered in Microsoft excel 2016, validated and cleaned before importing into Stata, version 13.0 (Stata Corp. LP, College Station, TX, United States of America) for analysis. Descriptive analyses were performed to summarize patients' sociodemographic and clinical characteristics. Chi Square (or Fisher's exact) test was used to look for significant associations between predictor and outcome variables at 95\%significance level. A multiple simple logistic regression was used to quantify the association between predictor variables and outcome variables.

\section{Ethical clearance}

This study was approved by National Health Science Research Committee (NHSRC) as part of the main study "Pathological profile of malignancies in northern Malawi-A retrospective study at Mzuzu Central Hospital" number 19/05/2316. Both the MCH Research and Publication Committee and the $\mathrm{MCH}$ Laboratory department consents were obtained for the study. The need for informed consent was exempted from the institutional review board due to the nature of the study, which involved a retrospective analysis of routinely collected data.

\section{RESULTS}

Within the 5-year period of the study (July 2013 to June 2018), a total of 500 biopsy reports were received from $\mathrm{KCH} / \mathrm{UNC}$ Pathology laboratory. The mean age of patients included in this study was $41.99 \pm 12.5$. The age range was $15-80$ years. Most of the cervical biopsies were from patients in the $31-40$ age group $(34.8 \% n=174)$. Twelve percent of the cervical biopsies were from HIV positive patients and $51 \%$ of the results had unknown HIV result (Table 1).

\section{Table 1. Demographic profile of cervical biopsies}

\begin{tabular}{lccc}
\hline Parameter & \multicolumn{2}{c}{ Biopsies analysed } \\
\cline { 2 - 4 } & & Frequency & Percentage (\%) \\
\hline Age (years) & 20 and below & 3 & 0.6 \\
& $21-30$ & 57 & 11.4 \\
\hline
\end{tabular}




\begin{tabular}{llcc}
\hline $31-40$ & 174 & 34.8 \\
$41-50$ & 132 & 26.4 \\
$51-60$ & 84 & 16.8 \\
$61-70$ & 29 & 5.8 \\
& Above 70 & 7 & 1.4 \\
HIV status & Missing & 14 & 2.8 \\
& Positive & 61 & 12.2 \\
& Negative & 184 & 36.8 \\
& Unknown (not documented) & 255 & 51.0 \\
\hline
\end{tabular}

Of all the cervical biopsies studied, 91 (18.2\%) were malignant. Squamous cell carcinoma (SCC) accounted for $85.7 \%$ of all malignant lesions (Table 2). Cervicitis accounted for $46.0 \%(\mathrm{n}=162)$ of the total nonmalignant lesions seen. Ten percent of cervicitis cases and $30.2 \%$ of CIN cases had HPV respectively (Table 2).

Table 2. Histopathological diagnosis of cervical biopsies

\begin{tabular}{lccc}
\hline Parameter & Frequency & $\begin{array}{l}\text { Within group } \\
\text { percentage(\%) }\end{array}$ & Percentage(\%)total \\
\hline Normal cervical tissue & $\mathbf{4 6}$ & & $\mathbf{9 . 2}$ \\
Nonmalignant lesions & $\mathbf{3 5 2}$ & & $\mathbf{7 0 . 4}$ \\
$\quad$ Cervicitis* & 162 & 46.0 & 32.4 \\
Cervical intraepithelial & 86 & 24.4 & 17.2 \\
neoplasm (CIN)* & & & \\
Endocervical polyp & 72 & 20.5 & 14.4 \\
Carcinoma in situ & 4 & 1.1 & 0.8 \\
Narborthian cyst & 4 & 1.1 & 0.8 \\
Schistosomiasis & 5 & 1.4 & 1.0 \\
Condloma (warts) & 11 & 3.1 & 2.2
\end{tabular}


Others

8
91

2.3

1.6

Malignant

91

18.2

Squamous cell carcinorma

78

85.7

15.6

Adenocarcinorma

8

8.8

1.6

Poorly differentiated

4

4.4

0.8

Carcino-sarcoma

1

1.1

0.2

Inconclusive result

11

2.2

Total

*Cervicitis with HPV=10\% (16/162)

$* \mathrm{CIN}$ with $\mathrm{HPV}=30.2 \%(26 / 86)$

$* \mathrm{CIN} 1=34.9 \%(30 / 86), \mathrm{CIN} 2=22.1 \%(19 / 86), \mathrm{CIN} 3=43.0 \%(37 / 86)$

The chances of developing cervical cancer increased with advancing age, with the risk becoming more prominent after age 60 years. Women aged 61-70 years were 6.2 times ( $\mathrm{OR}=6.2,95 \% \mathrm{CI}$ : 2.1 - 18.4) more likely to develop cervical cancer than those in the 21-30 years' age category. The odds of getting cancer were higher in women living with HIV. Women with HIV were more than twice (OR $=2.3,95 \%$ CI: $1.1-4.9)$ as likely to have cervical cancer as those who were HIV negative (Table 3 ). 
Table 3: Association between cancer, age and HIV status

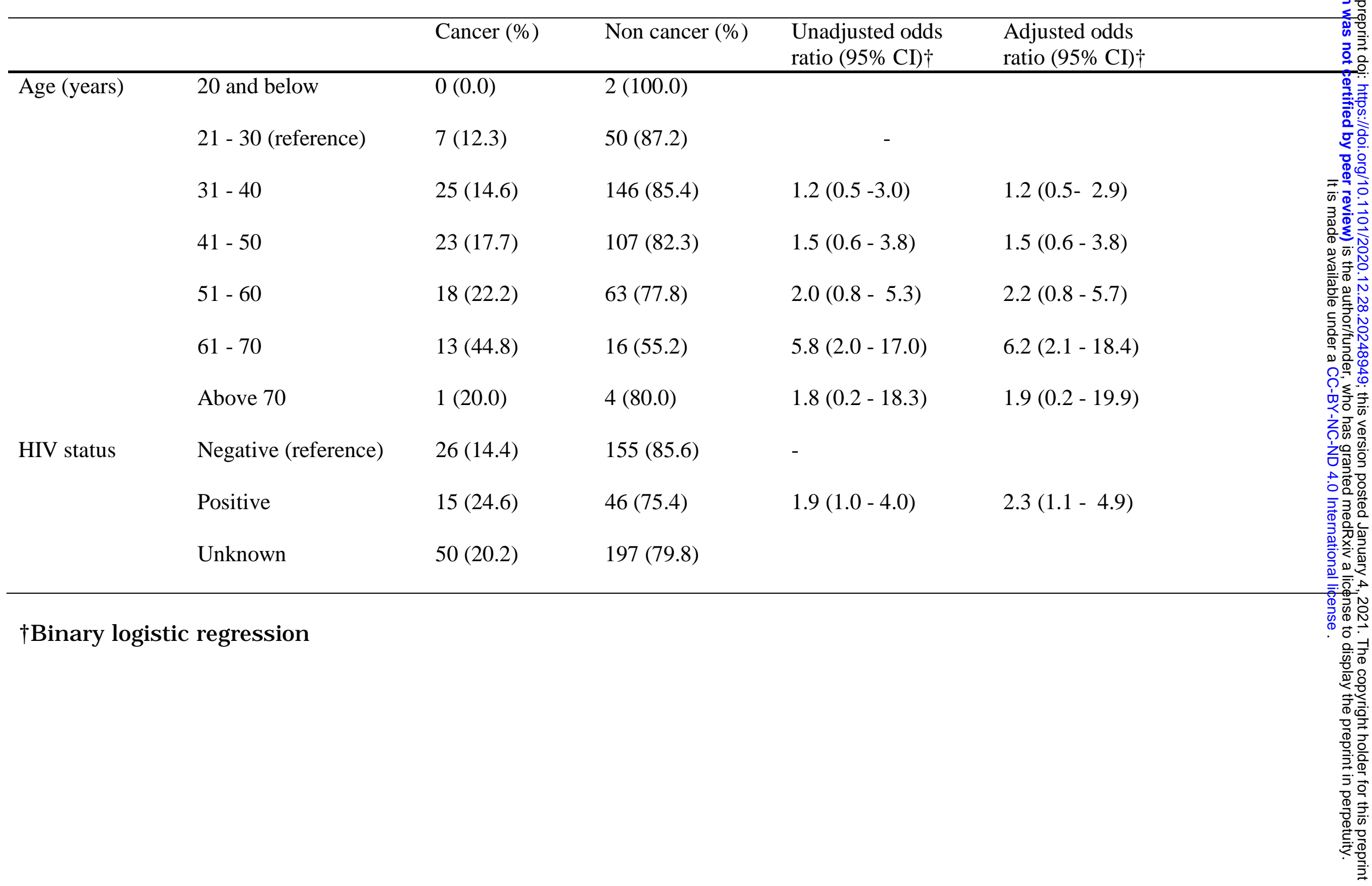


medRxiv preprint doi: https://doi.org/10.1101/2020.12.28.20248949; this version posted January 4, 2021. The copyright holder for this preprint (which was not certified by peer review) is the author/funder, who has granted medRxiv a license to display the preprint in perpetuity.

It is made available under a CC-BY-NC-ND 4.0 International license .

\section{DISCUSSION}

To the best of our knowledge, this is the first study conducted to determine the histopathological profile of cervical biopsies in a public tertiary hospital in Mzuzu, northern region of Malawi. This study found more benign conditions $(70.4 \% \mathrm{n}=352)$ than neoplastic malignant conditions $(18.2 \% n=91)$. This is in contrast with other studies undertaken in developing countries which reported more neoplastic malignant conditions than benign conditions $(8,9)$.

Our study found that cervicitis, an inflammatory disease comprising acute cervicitis and chronic non-specific cervicitis was the most common nonmalignant condition. It accounted for $46 \%$ of all the nonmalignant tumours and $32.4 \%$ of all cervical biopsies received in this study. This was consistent to a study conducted in Nigeria whose cervical biopsies included in their study was $37.5 \%(8)$. Most cases of cervicitis are often due to non-specific causes or infective agents(9). Cervicitis has been highly reported in previously studies in other countries $(12,13)$.

In this study CIN, a premalignant lesion ranked second in nonmalignant tumours accounting for $24 \%$ of all nonmalignant tumours and $17.2 \%$ of all cervical biopsies with the prevalence of CIN I, CIN II, CIN III of $34.9 \%, 22.1 \%$ and $43 \%$ respectively. This finding is comparable to a study conducted in Nigeria which reported CIN constituting $15 \%$ of all cervical biopsies reviewed(10). In that study however, there was a reduction in the prevalence of CIN from low grade CIN to high grade $\mathrm{CIN}(10)$. In our study, the high grade CIN (CIN III) was the most common. This finding indicates that invasive cervical cancer progresses from advanced stages of precancerous lesions. This shows that there is need to create community awareness and strengthen early cervical cancer screening for Malawi to have better outcomes.

In the current study $10 \%(n=16)$ of all the cervicitis cases and $30.2 \%(n=26)$ of all the CIN biopsies had HPV. This is comparable to a study conducted in United States of America (USA) which reported the overall HPV prevalence of $26.8 \%$ among US females aged 14 to 59 years $(n=1921)(11)$. This finding suggests that there is high rate of HPV infections, the causative agent of CIN in the younger age group(10). Unfortunately, the 
medRxiv preprint doi: https://doi.org/10.1101/2020.12.28.20248949; this version posted January 4, 2021. The copyright holder for this preprint (which was not certified by peer review) is the author/funder, who has granted medRxiv a license to display the preprint in perpetuity. It is made available under a CC-BY-NC-ND 4.0 International license .

data on population-based, age specific prevalence of HPV are not available in Malawi. However, WHO estimates that the overall HPV prevalence in Malawi is about 34\%(12).

The rate of malignant lesions (tumours) in our study (18.2\%) is comparable to $16.2 \%$ and $12.2 \%$ in studies conducted in Benin City(13), and in Enugu, in Nigeria(14) respectively. Studies done in South Africa, Saudi Arabia, India and United States, with malignant lesions at 2.42\%, 4.95\%, 5.5\% and 5.0\% respectively, are all at variance with the current study which explains that early cervical cancer screening helps to reduce the prevalence of cervical cancer(15-18).

Among the malignant tumours, SCC was the most common histological type of cervical cancer in our study. SCC accounted for $85.7 \%$ of malignant lesions cervical cancer and was also the most common diagnosis, at $15.6 \%$ of all cervical biopsies in this study. This is consistent with findings from other studies conducted in Nepal and in Pakistan which reported $84.2 \%, 92.56 \%$, and $73.5 \%$ respectively for squamous cell carcinoma out of all malignant lesions reviewed(19-21). As Faduyile et al. observed the high rate of SCC in Malawi and Africa could reflect the low uptake of VIA and Pap smear test which are capable of identifying dysplastic conditions before transformation to malignancy(11). This shows that there is need for Malawi to have well organized cervical cancer screening and Pap smear test to reduce the prevalence of SCC(2).

In our study, adenocarcinorma and poorly differentiated carcinorma were $8.8 \%$ and $4.4 \%$ respectively of the total malignant diagnosis. The prevalence of adenocarcinoma and poorly differentiated carcinoma observed in this study is in contrast to other studies done in Nigeria where one study found $5.8 \%$ and $2.0 \%$ of the total malignant lesions diagnosis and another found $6.0 \%$ and $1.0 \%$ respectively $(10,22)$. The high prevalence found in this study confirms a previous study findings by Chanza et al.(23). Chanza et al. reported that Malawian women delay to seek medical attention due to limited knowledge on symptoms and signs, limited financial resources, limited accessibility and unavailability of cancer screening facilities hence late diagnosis. These results show that early cervical cancer screening, increased awareness, better health care facilities, accessibility, improved histopathological confirmatory diagnosis and early treatment by surgeons, may reduce the cervical cancer burden in Malawi. 
medRxiv preprint doi: https://doi.org/10.1101/2020.12.28.20248949; this version posted January 4, 2021. The copyright holder for this preprint (which was not certified by peer review) is the author/funder, who has granted medRxiv a license to display the preprint in perpetuity. It is made available under a CC-BY-NC-ND 4.0 International license .

In the current study it has been observed that the diagnosis of cervical cancer was significantly associated with the age of the patients. The chances of developing cervical cancer increased with advancing age, with the risk becoming more prominent after age 60 years. Women aged 61-70 years were 6.2 times $(\mathrm{OR}=6.2,95 \% \mathrm{Cl}: 2.1-18.4)$ more likely to develop cervical cancer than those in the 21-30 years age category (Table 3). It is important to note that high quality screening programs are important to prevent cervical cancer among unvaccinated older women(24). None of the women in our study had received any HPV vaccine in their lifetime as the first round of the mass HPV vaccine in this country was administered in January 2019 mainly in schools, targeting 913 year old girls who had not yet become sexually active and the second round was given in January 2020. In Malawi, the integration of HPV vaccine programs with adequate screening programs in older women (aged 30-49 years) has the potential to reduce the burden of cervical cancer.

Malawi's HIV prevalence is one of the highest in the world, with $10.6 \%$ of adult population (aged 15-64) living with HIV (25). With such a high HIV prevalence in Malawi, there is an increased risk of AIDS-defining cancers including cervical cancer. In this study the probability of getting cancer were higher in women living with HIV. Women with HIV were more than twice (OR = 2.3, 95\% Cl: 1.1 - 4.9) as likely to have cervical cancer as those who were HIV negative (Table 3). This could be attributed to the reason that HIV-infected women are more likely than HIV-uninfected women to have incident and persistent HPV cervical infections(26). A twelve monthly cervical cancer screening, increased availability of dolutegravir (DTG) based antiretroviral treatment (ART) to HIV infected women now being provided in the country, routine viral load checks (at 6 months, 12 months and every 12 months since initiation) and timely switch to second line or third line regimens to ensure viral load suppression will eventually have an impact on benign lesions progressing to invasive cervical cancer(27). However, in this study almost half $(52.74 \%, \mathrm{n}=48)$ of all the women diagnosed with cervical cancer had an unknown HIV status. This calls for scaling up of HIV testing in cancer screening settings for early diagnosis and ART referral and further research is warranted on barriers among HIV-infected women to seeking cancer screening services despite already being in the health care system. 


\section{LIMITATIONS}

This study used available programme health facility data and histopathological reports on cervical cancer. The use of health facility data has its own limitations, such as incompleteness and bias in the sense that information is obtained only from people who came to the facility and underwent biopsy, leaving out those that did not seek medical care and or were not biopsied and therefore cannot be generalized to the general population.

The other limitation of this study is that it is a single-hospital-based review and as such inadequate to draw conclusions, but it does shed some light on pathological pattern of cervical cancer in Malawi.

Finally, this is a retrospective study so we could not be able to extract details for example in cases where tumours were diagnosed by screening or symptoms, presence or absence of the patient co-morbidities. Nevertheless, the comprehensive histopathological pattern of cervical cancer demonstrated by this study provides evidence that could be used to inform policies, strategies and intervention for prevention of cancer in Malawi.

\section{CONCLUSION}

The SCC was the commonest malignant condition and cervicitis and CIN were the most common non malignant conditions in all the women studied. Since the frequency of cervical cancer is high, there is need for well detailed national policies to be put in place to increase detection of pre-invasive lesions, which in turn will decrease the frequency of cervical cancer in the country. The presence of chronic non-specific cervicitis in women of reproductive age is infective in origin with its attending sequelae. Intensifying screening programmes among women and provision of long term ART to the HIV infected may offer an opportunity for appropriate interventions to reduce morbidity, mortality and reduce complications among these women. 
medRxiv preprint doi: https://doi.org/10.1101/2020.12.28.20248949; this version posted January 4, 2021. The copyright holder for this preprint (which was not certified by peer review) is the author/funder, who has granted medRxiv a license to display the preprint in perpetuity.

\section{REFERENCES}

1. Bruni L, Albero G, Serrano B et al. ICO/IARC Information Centre on HPVand Cancer (HPV Information Centre). Human Papillomavirus and Related Diseases in the World. Summary Report 17 June 2019. [Accessed 15 October 2019].

2. $\quad$ Bray F, Ferlay J, Soerjomataram I et al. Global cancer statistics 2018: GLOBOCAN estimates of incidence and mortality worldwide for 36 cancers in 185 countries. A Cancer J Clin. 2018;68(6):394-424.

3. Ferlay J, Soerjomataram I, Ervik M et al. IARC Publications Website GLOBOCAN 2012: Estimated Cancer Incidence, Mortality and Prevalence Worldwide in 2012 v1.0 [Internet]. WHO, International Research on Cancer. 2012 [cited 2019 Nov 18]. Available from: https://publications.iarc.fr/Databases/larcCancerbases/GLOBOCAN-2012-Estimated-Cancer-Incidence-Mortality-AndPrevalence-Worldwide-In-2012-V1.0-2012

4. Rudd P, Gorman D, Meja S et al. Cervical cancer in southern Malawi: A prospective analysis of presentation, management and outcomes. Malawi Med J. 2017;29(2):124-9.

5. Msyamboza KP, Ngwira B, D. The burden of selected chronic non-communicable diseases and their risk factors in malawi: Nationwide steps survey. PLoS One. $2011 ; 6(5): 6-11$.

6. Itano J, Taoka KN. Core curriculum for oncology nursing. Elsevier Saunders; 2005. $970 \mathrm{p}$.

7. National Statistical O. 2018 Malawi Population and Housing Census Main Report [Internet]. 2019. Available from:

http://10.150.72.21:6510/www.nsomalawi.mw/images/stories/data_on_line/demog raphy/census_2018/2018 Malawi Population and Housing Census Main Report.pdf

8. Omoniyi-esan OG, Osasan SA, Ojo OS. Non-neoplastic diseases of the cervix in Nigerians $\square$ : A histopathological study. African Heal Sci Vol. 2006;6(2):76-80.

9. Nwachokor FN, Forae GD. Morphological spectrum of non $\square$ neoplastic lesions of the uterine cervix in Warri , South $\square$ South , Nigeria. 2013;16(4):429-32.

10. Faduyile FA, Soyemi SS, Wright KO et al. Histopathological study of surgical cervical biopsies in Lagos ,. Trop J Obstet Gynaecol. 2017;34(2):124-8.

11. Dunne EF, Unger ER, Mcquillan G et al. Prevalence of HPV Infection Among Females in the United States. 2007;297(8):813-9.

12. Malawi Ministry of Health and Population, UNFPA. Malawi National cervical cancer control Strategy 2016-2020. Unfpa [Internet]. 2017;60. Available from: http://www.embase.com/search/results?subaction=viewrecord\&from=export\&id=L 71343074\%5Cnhttp://dx.doi.org/10.1158/1538-7445.AM2013-

ADV01\%5Cnhttp://fq5np7af6j.search.serialssolutions.com?sid=EMBASE\&issn=0 0085472\&id=doi:10.1158/1538-7445.AM2013-ADV01\&atitle=N

13. Obaseki D, Nwafor C. Cervical Cancer Screening In Benin City, South-South Nigeria [Internet]. Vol. 5, IOSR Journal of Dental and Medical Sciences (IOSRJDMS) e-ISSN. 2013 [cited 2019 Nov 18]. Available from: www.iosrjournals.org

14. Chukwuali LI, Onuigho WIB, Mgbor NC. Cervical cancer screening in Enugu, Nigeria. Trop J Obs Gynaecol. 2003;20:109-12. 
medRxiv preprint doi: https://doi.org/10.1101/2020.12.28.20248949; this version posted January 4, 2021. The copyright holder for this preprint (which was not certified by peer review) is the author/funder, who has granted medRxiv a license to display the preprint in perpetuity. It is made available under a CC-BY-NC-ND 4.0 International license.

15. Fonn S, Bloch B, Mabina $M$ et al. Prevalence of pre-cancerous leisons and cervical cancer in South Africa-A Multicentre study. SAMJ. 2002;92(2):148-56.

16. Balaha MH, Moghannum MS Al, Ghowinem NA et al. Cytological pattern of cervical Papanicolaou smear in eastern region of Saudi Arabia. J Cytol. 2011;28(4):173-177.

17. Patel MM, Pandya AN, Modi J. Cervical pap smear study and its utility in cancer screening, to specify the strategy for cervical cancer control. Natl J COMMUNITY Med. 2011;2(1):49-51.

18. Insinga RP, Glass AG, Rush BB. Diagnoses and outcomes in cervical cancer screening: A population-based study. Am J Obstet Gynecol. 2004 Jul;191(1):10513.

19. Okoye C. Histopathological pattern of cervical cancer in Benin City, Nigeria. J Med Investig Pract. 2014 Oct 1;9(4):147-147.

20. Pathak T, Pun C, Shrestha S et al. Incidence trends and histopathological pattern of cervical malignancies at BP koirala memorial centre hospital, Nepal. J Pathol Nepal. 2013;3:386-9.

21. Badar F, Anwar N, Meerza $F$ et al. Cervical Carcinoma in a Muslim Community. Asian Pacific J Cancer Prev. 2007;8:24-6.

22. Olu-Eddo AN, Ekanem VJ, Umannah I et al. A 20 year histopathological study of cancer of the cervix in Nigerians. Nig Q J Hosp Med. 2011 Apr;21(2):149-53.

23. Chadza E, Chirwa E, Maluwa A et al. Factors that contribute to delay in seeking cervical cancer diagnosis and treatment among women in Malawi. 2012;4(11):1015-22.

24. Soares GR, Vieira $R$ da $R$, Pellizzer EP et al. Indications for the HPV vaccine in adolescents: A review of the literature. J Infect Public Health [Internet]. 2015;8(2):105-16. Available from: http://dx.doi.org/10.1016/j.jiph.2014.08.011

25. Malawi Population-based HIV Impact Assessment Survey - MPHIA 2015 - 2016 [Internet]. Available from: https://phia.icap.columbia.edu/wpcontent/uploads/2019/08/MPHIA-Final-Report_web.pdf

26. Abraham AG, Strickler HD, Jing $Y$ et al. Invasive cervical cancer risk among HIVinfected women: A North American multi-cohort collaboration prospective study. J Acquir Immune Defic Syndr. 2013;62(4):405-13.

27. Ministry of Health and P. Malawi Guidelines for Clinical Management of HIV in Children and Adults (Third Edition, 2016) [Internet]. Lilongwe; 2016 [cited 2019 Nov 19]. Available from: www.hiv.health.gov.mw

\section{Declarations}

\section{i. Ethical approval and consent to participant}


medRxiv preprint doi: https://doi.org/10.1101/2020.12.28.20248949; this version posted January 4, 2021. The copyright holder for this preprint (which was not certified by peer review) is the author/funder, who has granted medRxiv a license to display the preprint in perpetuity.

It is made available under a CC-BY-NC-ND 4.0 International license .

This study was approved by National Health Science Research Committee as part of the main study "Pathological profile of malignancies in northern Malawi-A retrospective study at Mzuzu Central Hospital" number 19/05/2316. Both the Mzuzu Central Hospital Research and Publication Committee and the Mzuzu Central Hospital Laboratory department consents were obtained for the study. The need for informed consent was exempted from institutional review board due to the nature of the study, which involved a retrospective analysis of routinely collected data.

ii. Consent for publication: Not applicable

iii. Availability of data and materials

The datasets used and/or analyzed during the current study are available from the corresponding author on reasonable request. Email: kasekapaul2016@gmail.com

ORCID: 0000-0002-6651-8000

iv. Competing interests: The authors declare that they have no competing interest

v. Funding

The study's data collection, analysis, interpretation of data and manuscript writing was funded by Pingtung Christian Hospital, Taiwan through Luke International Norway (LIN), Malawi, Grant Number: PS-IR-108001

\section{vi. Authors contributions}

PUK and FWS conceived and designed the study. AK, CC, PK, JU and BCM contributed to development of the study protocol and supervised data collection and entry. AK analyzed the data and PUK drafted the manuscript. All authors read and approved the final manuscript.

\section{vii. Acknowledgements}

The authors are sincerely grateful to all the data collectors and the Laboratory manager for providing the data. The Pingtung Christian Hospital through Luke International Norway (LIN) is also appreciated for financial support 